\title{
Role of $C$ reactive protein in evaluating the extent of myocardial inflammation in acute myocarditis
}

Orly Goitein ${ }^{1 *}$, Avi Sabag ${ }^{2}$, Rafi Koperstein ${ }^{2}$, Ashraf Hamdan², Elio Di Segni', Eli Konen', Shlomi Matetzky ${ }^{2}$

From 18th Annual SCMR Scientific Sessions

Nice, France. 4-7 February 2015

\section{Background}

Cardiac MRI (CMR) is an excellent modality for myocardial tissue characterization, allowing demonstration and quantification of myocardial damage using late Gadolinium enhancement (LGE) sequence. C Reactive Protein (CRP) has been shown to be a prognostic marker in lymphocytic myocarditis. The purpose of this study was to study the correlation between CRP levels and the extent of myocardial damage in patients diagnosed with myocarditis.

\section{Methods}

The study cohort included 47 patients (Mean age $32.5 \pm 12$, $89 \%$ males) admitted to the heart center with MRI proven acute myocarditis. Demographic, clinical, laboratory echocardiographic and CMR data was collected. CMR was performed using a $1.5 \mathrm{~T}$ scanner (Signa HDX GE medical systems) using a standardized protocol including SSFP and LGE sequnces. LGE was quantified as percentage of the left ventricular (LV) mass. Patients were divided into two groups: $\mathrm{LGE}<10 \%$ of LV mass and LGE $>10.1 \%$ of LV mass. These two groups were compared in regards to CRP levels and left ventricular (LV) function.

\section{Results}

CRP levels were positively correlated with the myocardial damage; in the LGE $<10 \%$ group CRP was $54.6 \pm 56$, in the and $\mathrm{LGE}>10.1 \%$ group CRP was $104 \pm 68$ (P value $=0.022$ ). This correlation was maintained also when CRP was divided into thirtailes ( $\mathrm{P}$ value $=0.004$ ). $\mathrm{LV}$ ejection fraction was $59.9 \% \pm 6.7$ VS $52.2 \% \pm 12$ for the lower and mid LGE thirtailes and upper LGE thirtaile, respectively ( $P$ value $=0.023$ )

No correlation was found between the extent of myocardial damage (\% LGE) and the CPK and Troponin levels or any of the baseline characteristics (table 1).

\section{Conclusions}

CRP was significantly and positively correlated with the extent of myocardial damage as quantified by CMR. It may serve as a simple yet valuable tool to predict LV damage and dysfunction in patients presenting with acute myocarditis.

Table 1 Late Gd enhancement (LGE) percentage baseline characteristics and CRP CPK and Troponin levels

\begin{tabular}{cccc}
\hline & $\mathrm{LGE}<10 \% \mathrm{~N}=16$ & $\mathrm{LGE} \geq 10 \% \mathrm{~N}=31$ & $\mathrm{P}$ value \\
\hline Age (Mean $\pm \mathrm{SD})$ & $30.7 \pm 11$ & $34.4 \pm 14$ & 0.352 \\
\hline Diabetes mellitus & 0 & 6.5 & 0.541 \\
\hline Hypertension & 0 & 9.7 & 0.541 \\
\hline Dyslipidemia & 0 & 16.1 & 0.150 \\
\hline Obesity & 56.3 & 53.3 & 1 \\
\hline Smoker & 31.3 & 29 & 1 \\
\hline CPK & $560 \pm 680$ & $612 \pm 427$ & 0.779 \\
\hline Troponin & $19.5 \pm 27$ & $12 \pm 9.5$ & 0.310 \\
\hline Troponin upper thirtile & 31.3 & 29 & 1 \\
\hline LVEF & & & \\
\hline CRP & $54.6 \pm 56$ & $104 \pm 68$ & 0.022 \\
\hline CRP upper thirtaile & 21.4 & 63 & 0.012 \\
\hline
\end{tabular}

CPK- Creatinin Phosphosokinase LVEF- Left Ventricular Ejection Fraction CRP-C Reactive protein 


\section{Funding}

No external funding was used for this study.

\section{Authors' details}

'Diagnostic Imaging, Sheba Medical Center, Tel Hashomer, Israel. ${ }^{2}$ Heart

Center, Sheba Medical Center, Tel Hashomer, Israel.

Published: 3 February 2015

doi:10.1186/1532-429X-17-S1-P291

Cite this article as: Goitein et al:: Role of $C$ reactive protein in evaluating the extent of myocardial inflammation in acute myocarditis. Journal of Cardiovascular Magnetic Resonance 2015 17(Suppl 1):P291.

Submit your next manuscript to BioMed Central and take full advantage of:

- Convenient online submission

- Thorough peer review

- No space constraints or color figure charges

- Immediate publication on acceptance

- Inclusion in PubMed, CAS, Scopus and Google Scholar

- Research which is freely available for redistribution

Submit your manuscript at www.biomedcentral.com/submit 